University of Nebraska - Lincoln

DigitalCommons@University of Nebraska - Lincoln

\title{
Stress orientations of Taiwan Chelungpu-Fault Drilling Project (TCDP) hole-A as observed from geophysical logs
}

\author{
Hung-Yu Wu \\ National Central University \\ Kuo-Fong $\mathrm{Ma}$ \\ National Central University \\ Mark Zoback \\ Stanford University, zoback@stanford.edu \\ Naomi Boness \\ Stanford University \\ Hisao Ito \\ Japan Agency for Marine-Earth Science and Technology \\ See next page for additional authors
}

Follow this and additional works at: https://digitalcommons.unl.edu/usgsstaffpub

Part of the Earth Sciences Commons

Wu, Hung-Yu; Ma, Kuo-Fong; Zoback, Mark; Boness, Naomi; Ito, Hisao; Hung, Jih-Hao; and U.S. Geological Survey, "Stress orientations of Taiwan Chelungpu-Fault Drilling Project (TCDP) hole-A as observed from geophysical logs" (2007). USGS Staff -- Published Research. 449.

https://digitalcommons.unl.edu/usgsstaffpub/449

This Article is brought to you for free and open access by the US Geological Survey at DigitalCommons@University of Nebraska - Lincoln. It has been accepted for inclusion in USGS Staff -- Published Research by an authorized administrator of DigitalCommons@University of Nebraska - Lincoln. 


\section{Authors}

Hung-Yu Wu, Kuo-Fong Ma, Mark Zoback, Naomi Boness, Hisao Ito, Jih-Hao Hung, and U.S. Geological Survey 


\title{
Stress orientations of Taiwan Chelungpu-Fault Drilling Project (TCDP) hole-A as observed from geophysical logs
}

\author{
Hung-Yu Wu, ${ }^{1}$ Kuo-Fong Ma, ${ }^{1}$ Mark Zoback, ${ }^{2}$ Naomi Boness, ${ }^{2}$ Hisao Ito, ${ }^{3}$ \\ Jih-Hao Hung, ${ }^{1}$ and Stephen Hickman ${ }^{4}$ \\ Received 12 September 2006; revised 31 October 2006; accepted 6 November 2006; published 5 January 2007.
}

[1] The Taiwan Chelungpu-fault Drilling Project (TCDP) drilled a 2-km-deep research borehole to investigate the structure and mechanics of the Chelungpu Fault that ruptured in the $1999 \mathrm{M}_{\mathrm{w}}$ 7.6 Chi-Chi earthquake. Geophysical $\operatorname{logs}$ of the TCDP were carried out over depths of 500-1900 m, including Dipole Sonic Imager (DSI) logs and Formation Micro Imager (FMI) logs in order to identify bedding planes, fractures and shear zones. From the continuous core obtained from the borehole, a shear zone at a depth of 1110 meters is interpreted to be the Chelungpu fault, located within the Chinshui Shale, which extends from 1013 to 1300 meters depth. Stress-induced borehole breakouts were observed over nearly the entire length of the wellbore. These data show an overall stress direction $\left(\sim \mathrm{N} 115^{\circ} \mathrm{E}\right)$ that is essentially parallel to the regional stress field and parallel to the convergence direction of the Philippine Sea plate with respect to the Eurasian plate. Variability in the average stress direction is seen at various depths. In particular there is a major stress orientation anomaly in the vicinity of the Chelungpu fault. Abrupt stress rotations at depths of $1000 \mathrm{~m}$ and $1310 \mathrm{~m}$ are close to the Chinshui Shale's upper and lower boundaries, suggesting the possibility that bedding plane slip occurred during the Chi-Chi earthquake. Citation: Wu, H.-Y., K.-F. Ma, M. Zoback, N. Boness, H. Ito, J.-H. Hung, and S. Hickman (2007), Stress orientations of Taiwan Chelungpu-Fault Drilling Project (TCDP) hole-A as observed from geophysical logs, Geophys. Res. Lett., 34, L01303, doi:10.1029/2006GL028050.

\section{Introduction}

[2] Taiwan Chelungpu drilling project (TCDP) drilled a 2-km-deep hole, $2.4 \mathrm{~km}$ to the east of the surface rupture of the 1999 Chi-Chi earthquake (Mw7.6), near the town of Dakeng (Figure 1a). The $\sim \mathrm{N}-\mathrm{S}$ trend of the Chelungpu-fault is a major $60-\mathrm{km}$ structure that dips $\sim 30^{\circ}$ to the east (Figure 1b). Geological investigations showed that the 1999 Chi-Chi earthquake principally slipped within (Figure 1b), and parallel to the bedding of the Pliocene Chinshui Shale [Lee et al., 2002]. The subsurface location of the Chinshui Shale was determined to be at a depth of approximately $1000 \mathrm{~m}$ depth based on high-resolution

\footnotetext{
${ }^{1}$ Institute of Geophysics, National Central University, Chung-Li, Taiwan.

${ }^{2}$ Department of Geophysics, Stanford University, Stanford, California, USA.

${ }^{3}$ Japan Agency for Marine-Earth Science and Technology, Tokyo, Japan.

${ }^{4}$ U.S. Geological Survey, Menlo Park, California, USA.
}

Copyright 2007 by the American Geophysical Union. 0094-8276/07/2006GL028050\$05.00 seismic reflection profiles [Wang et al., 2002]. The TCDP carried out continuous coring from depths of 500-2000 m. Geophysical well logs were run to collect seismic velocities, densities, and anisotropy and borehole images. Based on the result of T. S. Lin et al. (Stratigraphy and geology of the Taiwan Chelungpu-fault Drilling Project-A borehole and its neighboring region, central Taiwan, submitted to Terrestrial Atmospheric and Oceanic Sciences, 2006), it suggested that the stratigraphy is as follows: Kueichulien formation of late Miocene to early Pliocene at depths of 1313-1707 m; Chinshui Shale of last Pliocene at depths of 1013-1313 m; and Cholan formation of late Miocene to early Pleistocene at depths of $0-1013 \mathrm{~m}$ and $1707-2003 \mathrm{~m}$.

[3] The geophysical logging data provides the opportunity to measure the physical properties of the fault zones and surrounding formations. A Formation Micro Scanner (FMS) [Ekstrom et al., 1987] and Formation Micro Imager (FMI) data are utilized to record high-resolution borehole electrical images to identify stress-induced borehole failures, bedding, fractures and fault zones. The FMS log was run in the upper section of the borehole $(500-1300 \mathrm{~m})$; resulting in coverage of borehole circumference of $60 \%$. For the lower section (1280-1860 m), the FMI was run and obtained coverage of over $90 \%$ of the borehole wall.

\section{Borehole Breakout and Fracture Orientation From Image Logs}

[4] Borehole breakouts result from localized failure around a borehole in response to horizontal compression [Bell and Gough, 1979; Zoback et al., 1985]. In a vertical borehole, the breakout directions are parallel to the minimum horizontal principal stress $\left(\mathrm{S}_{\mathrm{hmin}}\right)$. Due to the symmetry of the stress concentration around the borehole, breakouts occur in pairs, offset by $180^{\circ}$. Figure 2 presents an example formation micro image from FMI for the depth of $1408.9-1411.3 \mathrm{~m}$. The breakouts appear as dark zones of lower electrical conductivity $180^{\circ}$ apart. Localized breakout rotations indicate stress perturbations associated with slip on active fault intersected by the borehole [Barton and Zoback, 1994]. Thus, by investigating localized changes in breakout direction, active fault zones can be identified. Figure 3a shows a profile of the orientation of the minimum horizontal principal stress $\left(\mathrm{S}_{\mathrm{hmin}}\right)$ from $500-1860 \mathrm{~m}$ (solid cycles) based on wellbore breakout directions averaged over $2 \mathrm{~m}$ depth intervals. The borehole azimuth (open cycles) during drilling is shown for reference. As shown in Figure 3c, the borehole deviation from vertical is very small $\left(<3^{\circ}\right)$ except near bottom of the hole where it deviated slightly. Comparing the breakout direction and hole azimuth can help us to determine whether the failures results from changes in stress 
(a)

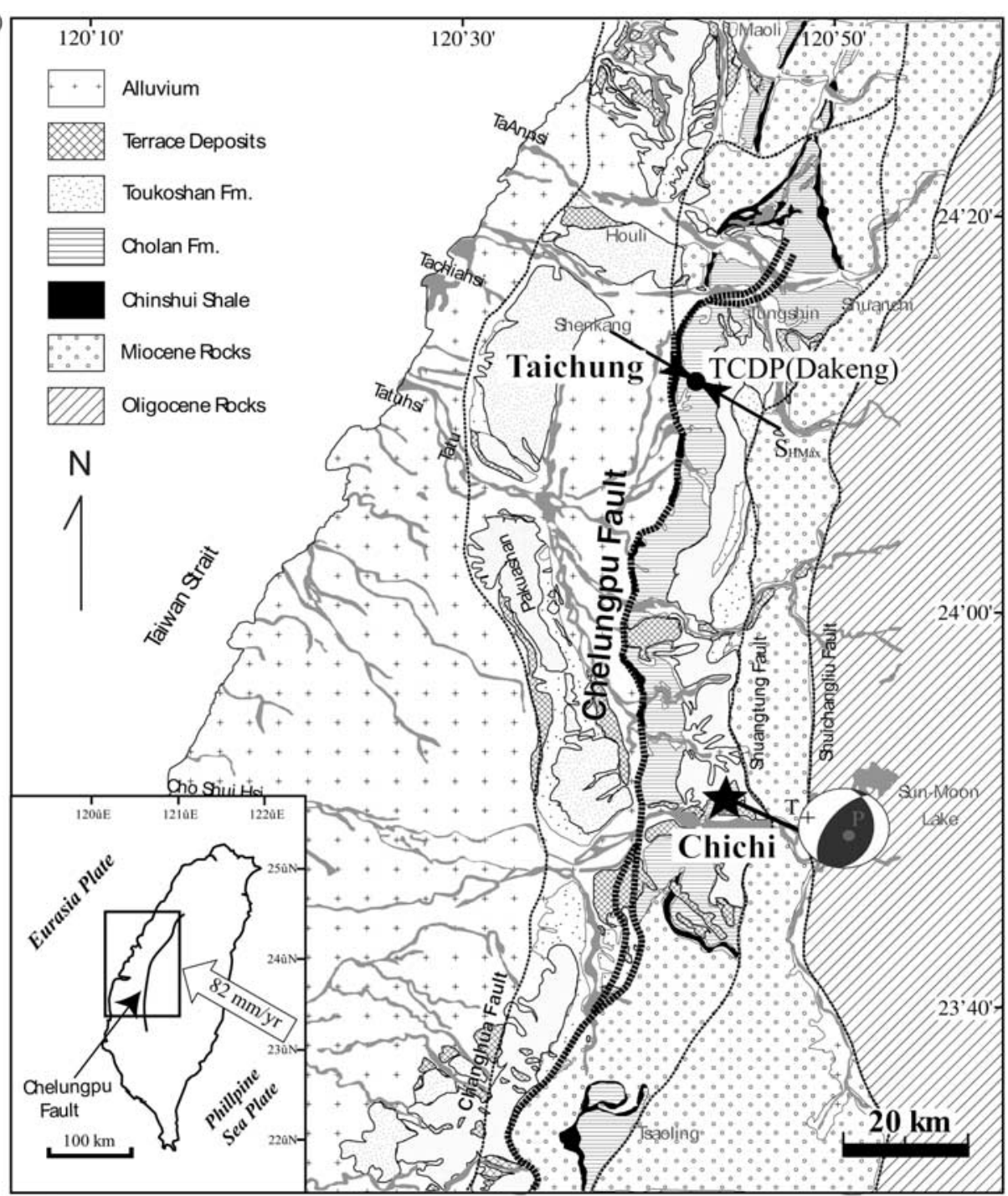

(b)

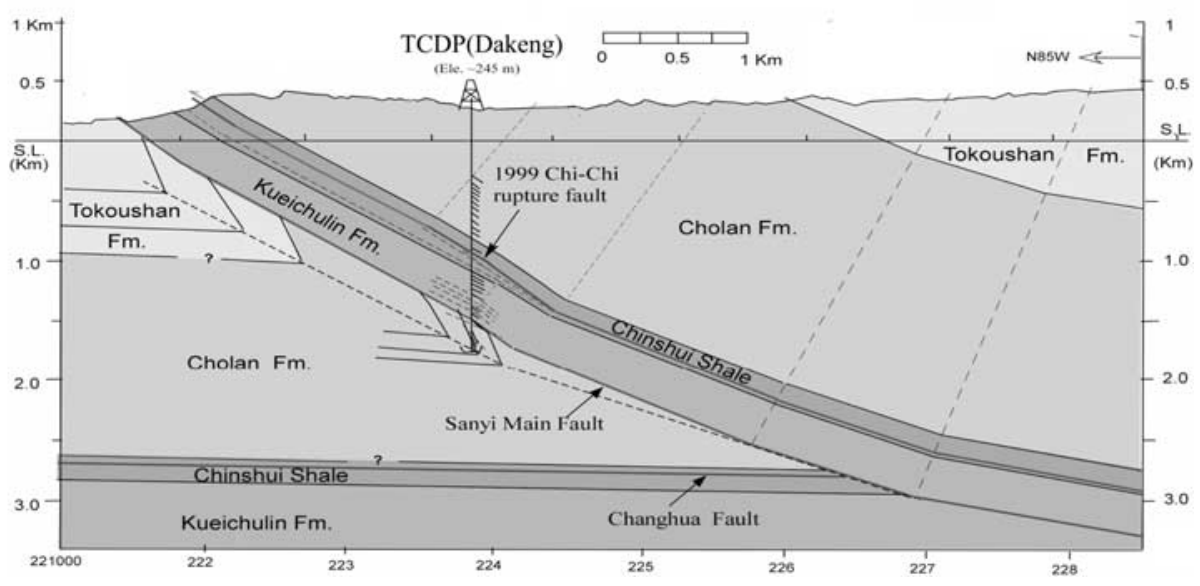

Figure 1 


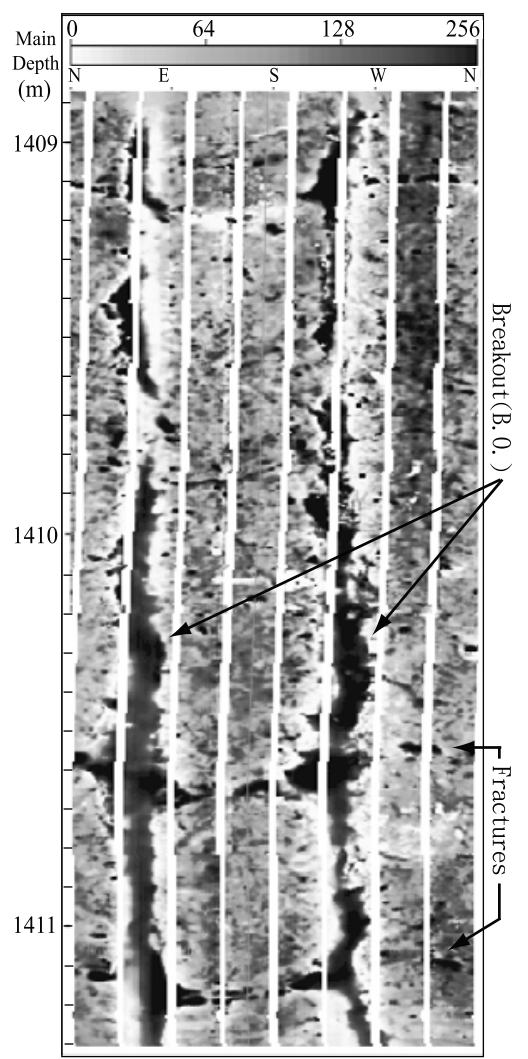

Figure 2. Sample of FMI image, the straight dark bands indicate stress-induced wellbore breakouts.

direction or from drilling-induced erosion of the wellbore wall [see Plumb and Hickman, 1985]. The borehole azimuth differs from the observed orientation of breakout pairs, suggesting that the breakout was resulted from stress rather than drilling. The borehole breakouts pairs obtained from the FMS data indicate an average orientation of $\mathrm{N} 25^{\circ} \mathrm{E}$ over most of the 500-1800 m interval (Figure 3a). This orientation corresponds to a direction of $\mathrm{S}_{\mathrm{H} \max }$ of $\mathrm{N} 115^{\circ} \mathrm{E}$ (Figure $3 \mathrm{~b}$ ) which is essentially parallel to the regional stress direction in the Taiwan region that results from the convergent Philippine Sea Plate to the Eurasian plate [Kao and Angelier, 2001] (see inset of Figure 1a). The deviation of TCDP-A was $<4^{\circ}$ from the surface to a depth $1600 \mathrm{~m}$, and only in the lower part of the hole (deeper than $1835 \mathrm{~m}$ ) did the deviation of the borehole exceed $>12^{\circ}$ where almost no breakouts were observed. Hence, the effect of borehole deviation was ignored in this study [Peska and Zoback, 1995].
[5] As shown in Figure 3b, minor fluctuations of the orientation of $\mathrm{S}_{\mathrm{Hmax}}$ are seen at a variety of depths, with a major change of the $S_{H \max }$ direction seen between $950 \mathrm{~m}$ and $1310 \mathrm{~m}$ Below $1500 \mathrm{~m}$, very few breakouts are observed and it is difficult to assess whether the variation of orientations observed are statistically significant.

[6] As mentioned above, the locations of abrupt breakout rotations indicate the presence of active shear zones. In total, five zones with significant rotation of the $\mathrm{S}_{\mathrm{Hmax}}$ at the depths of $1000 \mathrm{~m}, 1110 \mathrm{~m}, 1230 \mathrm{~m}, 1310 \mathrm{~m}$ and $1460 \mathrm{~m}$ were identified within the depths of $600-1500 \mathrm{~m}$. These zones are concentrated in the depth interval 980$1300 \mathrm{~m}$, corresponding to the lithology in the Chinshui Shale $1500 \mathrm{~m}$ (Figure 3). The abrupt stress rotations at depths of $1000 \mathrm{~m}$ and $1310 \mathrm{~m}$ are close to the Chinshui Shale's upper and lower boundaries, suggesting the possibility that bedding plane slip occurred during the Chi-Chi earthquake. In addition to these rotations, the most significant changes in the $\mathrm{S}_{\mathrm{Hmax}}$ direction occur near depths of $1110 \mathrm{~m}$ and $1230 \mathrm{~m}$.

[7] Numerous fractures, faults and bedding-planes are obvious in the image logs. Figure $3 \mathrm{c}$ shows the distribution of number of visible fractures and faults in 10-m intervals. $63 \%$ of the fractures $(4,473$ of 7,093$)$ are found between 500 and $1100 \mathrm{~m}$ with nearly $50 \%$ of the fractures concentrated between 900 and $1100 \mathrm{~m}$. The number of fractures decreases gradually between 1100 and $1500 \mathrm{~m}$ and then more rapidly below $1500 \mathrm{~m}$ where they are nearly absent.

\section{Physical Properties From Geophysical Logs}

[8] Geophysical logs were run from $500 \mathrm{~m}$ to $1860 \mathrm{~m}$ to obtain the physical properties of fault zones and adjacent damage zones, including P \& S wave velocities, density, resistivity, and gamma ray. The logs sample these properties every $15 \mathrm{~cm}$. The velocity logs show a gradual increase in $\mathrm{P}$ and $\mathrm{S}$ wave velocity (Figures $4 \mathrm{~b}$ and $4 \mathrm{c}$ ) due to the increase in confining pressure with depth. The $\mathrm{P}$ wave (compressional) velocity ranges from $2.27 \mathrm{~km} / \mathrm{s}$ at depth $551 \mathrm{~m}$ to $5.47 \mathrm{~km} / \mathrm{s}$ at depth $1668 \mathrm{~m}$. The S wave (shear) increases from $1.4 \mathrm{~km} / \mathrm{s}$ at a depth of $597 \mathrm{~m}$ to $2.98 \mathrm{~km} / \mathrm{s}$ at a depth of $1705 \mathrm{~m}$. Overall average of P-wave velocity is $3.81 \mathrm{~km} / \mathrm{s}$ and $\mathrm{S}$-wave velocity value is $1.86 \mathrm{~km} / \mathrm{s}$. The overall resistivity of the formations encountered in TCDP is low from $20 \mathrm{ohm}-\mathrm{m}$ to $50 \mathrm{ohm}-\mathrm{m}$ between depths of $587 \mathrm{~m}$ to $1856 \mathrm{~m}$ (Figure 4d). Depths of abnormal geophysical properties can be identified at depths where the velocities and resistivities are lower than the average trend with depth. The gray bars in the lithologic column represent fault zones observed in the core (E.-C. Yeh, personal communication,

Figure 1. (a) Geology map of the region near the TCDP drill site (solid dot) (H. Tanaka, personal communication, 2006). Surface rocks near the drill site are identified as Cholan Formation and Chinshui Shale. The drill site is in the town of Dakeng, 2.5 kilometer east to the Chelungpu fault rupture (wide black dash line). The nearby faults from west to east are Changhua fault, Shuangtung fault and Shuichangliu fault (black dash lines). The regional tectonic stress of Taiwan is $\mathrm{N} 126^{\circ} \mathrm{E}$ as shown in inset [Kao and Angelier, 2001]. The slip direction of the Philippine Sea Plate with respect to the Eurasian Plate is in this same direction. The convergence rate is $82 \mathrm{~mm} \mathrm{year}^{-1}$. The location of mainshock (asterisk) and its focal mechanism are also shown. (b) A geological cross-section near the drill site [Yue et al., 2005]. The Chelungpu fault dips 30 degrees east. TCDP drilled a $1.8 \mathrm{~km}$ depth hole through from Cholan Formation to Chinshui Shale and Kueichuline Formation, then, to Cholan Formation. The Sanyi fault is interpreted to be at the base of the Kuichulin Formation with some uncertainties shown by dash line below it. 


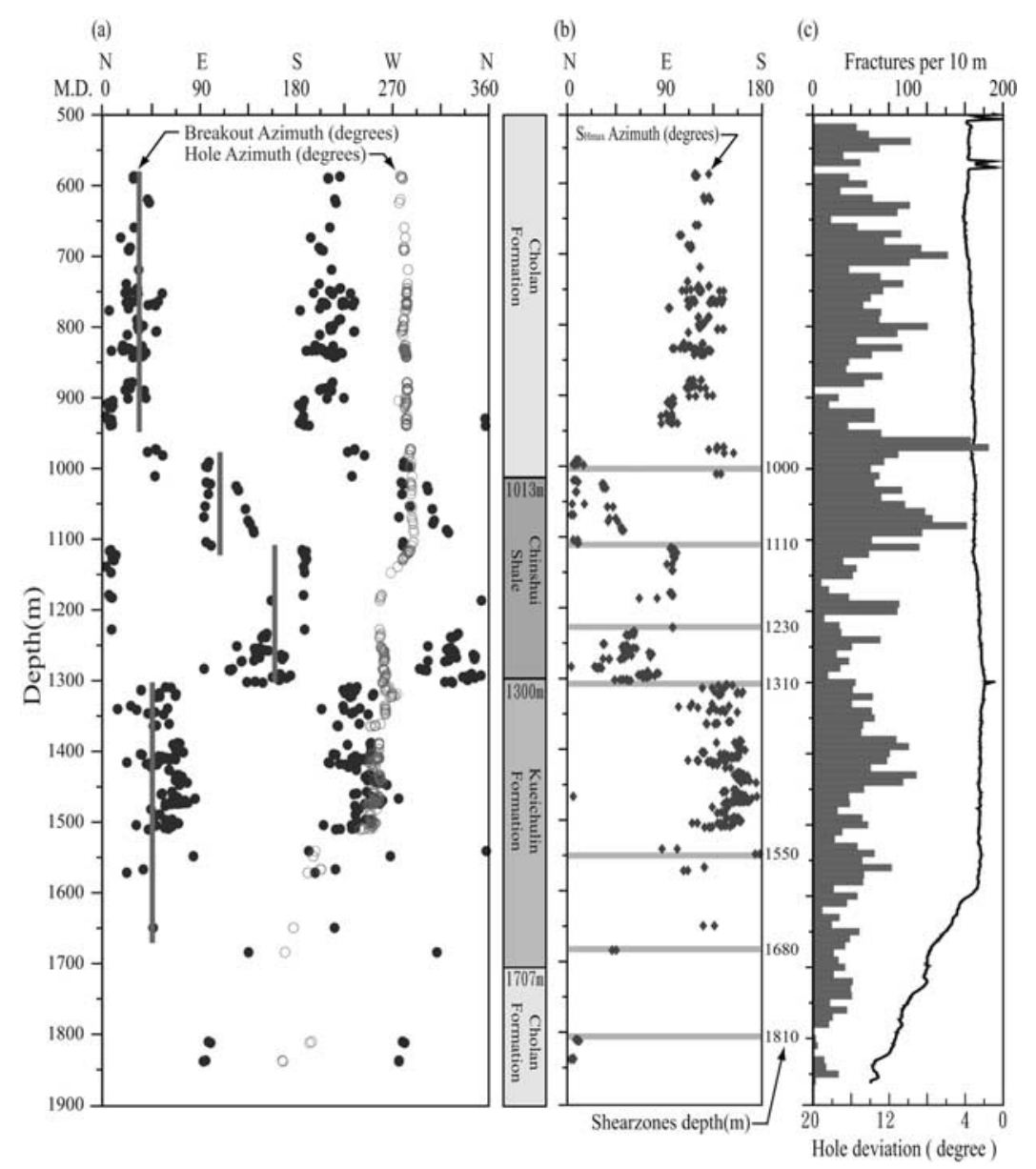

Figure 3. (a) The directions of breakouts (averaged over 2-meter intervals) are shown by filled dots and hole azimuth (represented by open dots) from depth of $500 \mathrm{~m}$ to $1900 \mathrm{~m}$. The gray bars represent the average value in different depths. The lithology from T.-S. Lin (personal communication, 2006) is also shown for references. (b) The maximum horizontal principal stress (solid diamond) acquired from the breakout data. Gray bands denote the depths at which active shear zones were penetrated as indicated by the abrupt changes of stress direction with depth. (c) Fracture density (per 10 meter interval). The borehole deviation from vertical is shown by the solid curve.

2006). There is some degree of correlation between fault zones and anomalous geophysical properties as observed in other fault zone drilling project [e.g., Boness and Zoback, 2004]. However, this correlation is not compelling as a number of zone of anomalous geophysical properties do not correlate with identified shear zones and some of the shear zones identified in the core are not associated with anomalous properties.

[9] We can also compare the geophysical logs with the zones of localized $\mathrm{S}_{\mathrm{Hmax}}$ perturbations seen in Figure $3 \mathrm{~b}$, which are shown by shaded in gray bands in Figures $4 a-4 f$. The zone identified from the discontinuous rotation of $\mathrm{S}_{\mathrm{Hmax}}$ at the depth of $1110 \mathrm{~m}$ corresponds to the most significant changes in $\mathrm{Vp}, \mathrm{Vs}$, and resistivity. It is also consistent with the fault zone identified from the core. Considering the observations from all of the various geophysical logs and the faults identified from cores, it suggests that the shear zone at the depth of about $1110 \mathrm{~m}$ is the most recent shear zone related to the 1999 Chi-Chi earthquake. Other zones of anomalous breakout rotations could be associated with co-seismic slip on secondary fault planes that moved during the Chi-Chi earthquake or slip that occurred during historical events. The geophysical logs close to the depth of 1680-1707 m show significant changes in $\mathrm{Vp}$, and Vs, which have good correlation to the fracture zone observed from the core. This shear zone could be related to the SanYi fault beneath the Chelungpu fault as shown in Figure 1b. As mentioned above, the abrupt stress rotations at depths of $1000 \mathrm{~m}$ and $1310 \mathrm{~m}$ are close to the Chinshui Shale's upper and lower boundaries, suggesting the possibility that bedding plane slip occurred during the Chi-Chi earthquake.

\section{Conclusions}

[10] Continuous core, geophysical logs data and observations of stress-induced borehole breakouts were collected from the entire depth of TCDP hole-A. These data clearly to present the overall stress direction at the site, which is consistent with the regional stress field as well as anomalous stress rotations associated with the faults that cut through the hole. Active shear zones are identified at depths 


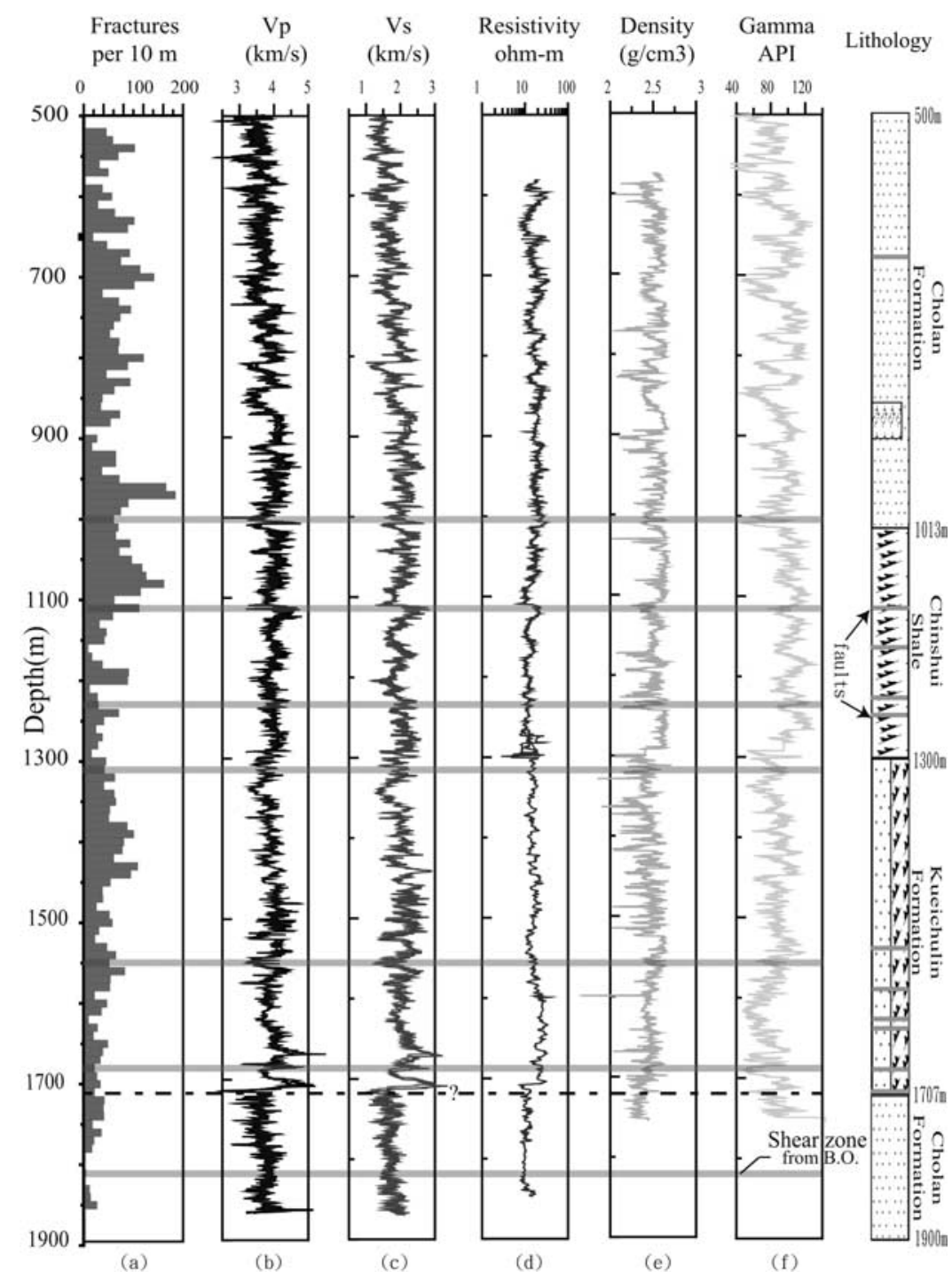

Figure 4. (a) Fractures density picked from FMS and FMI in 10 meter intervals. (b) P-wave velocity, (c) S-wave velocity, (d) Resistivity, (e) Density, and (f) Gammy ray and lithology from core descriptions. The zones with localized stress rotations are shown on geophysical logs with thick gray lines. The fault zones identified from the on-site core description (E.-C. Yeh, personal communication, 2006) are shown by gray bars in the lithology column.

of $1110 \mathrm{~m}$ and $1680-1707 \mathrm{~m}$ related to Chelungpu fault and SanYi fault, respectively. The shear zone at the depth $1110 \mathrm{~m}$ shows the most consistent features with fracture zones observed in core, the rotations of $\mathrm{S}_{\mathrm{Hmax}}$ and anomalies in velocities and resistivity, suggest that this fault is most likely related to the 1999 Chi-Chi earthquake. Other observations were found for the rotation of the $S_{H \max }$ direction indicate other active faults as well as bedding plane slip at the boundaries of different formations.

[11] Acknowledgments. The authors would like to thank the members of the TCDP science team. H. Tanaka in Tokyo University is thanked for his valuable comments and discussion. We also thank Schlumberger Corporation for discussion and comments and GeoMechanics International (GMI) for use of their image analysis software. We appreciate the helpful suggestions of Timothy Byrne. This research was supported by National Science Council of Republic of China, Taiwan, NSC 92-2116-M-008-006-, with TEC Contribution Number 00001, and the Stanford Rock and Borehole Geophysics (SRB) consortium.

\section{References}

Barton, C. A., and M. D. Zoback (1994), Stress perturbations associated with active faults penetrated by boreholes: Possible evidence for nearcomplete stress drop and new technique for stress magnitude measurement, J. Geophys. Res., 99, 9373-9390.

Bell, J. S., and D. J. Gough (1979), Northeast southwest compressive stress in Alberta: Evidence from oil wells, Earth Planet. Sci. Lett., 45, 475482.

Boness, L. N., and M. D. Zoback (2004), Stress-induced seismic velocity anisotropy and physical properties in the SAFOD Pilot Hole in Parkfield, Geophys. Res. Lett., 31, L15S17, doi:10.1029/2003GL019020.

Ekstrom, M. P., C. A. Dahan, M. Y. Chen, P. M. Lloyd, and D. J. Rossi (1987), Formation imaging with microelectrical scanning arrays, Log Anal., 28, 294-306.

Kao, H., and J. Angelier (2001), Stress tensor inversion for the Chi-chi earthquake sequence and its implications on regional collision, Bull. Seismol. Soc. Am., 91, 1028-1040.

Lee, J. C., H. T. Chu, J. Angelier, Y. C. Chan, J. C. Hu, C. Y. Lu, and R. J. Rau (2002), Geometry and structure of northern surface ruptures of the $1999 \mathrm{Mw}=7.6 \mathrm{Chi}-\mathrm{Chi}$ Taiwan earthquake: Influence from inherited fold belt structures, J. Struct. Geol., 24, 173-192. 
Peska, P., and M. D. Zoback (1995), Observations of borehole breakouts and tensile wall-fractures in deviated boreholes: A technique to constrain in situ stress and rock strength, in Rock Mechanics, Proceedings of the 35th U.S. Symposium, edited by J. J. K. Daemen and R. A. Schultz, pp. 319-325, A. A. Balkema, Brookfield, Vt.

Plumb, R. A., and S. H. Hickman (1985), Stress-induced borehole elongation: A comparison between the four-arm dipmeter and the borehole televiewer in the Auburn geothermal well, J. Geophys. Res., 90, 55135522.

Wang, C. Y., C. L. Li, and H. Y. Yen (2002), Mapping the northern portion of the Chelungpu fault, Taiwan by shallow reflection seismics, Geophys. Res. Lett., 29(16), 1790, doi:10.1029/2001GL014496.

Yue, L. F., J. Suppe, and J. H. Hung (2005), Structural geology of a classic thrust belt earthquake: The 1999 Chi-Chi earthquake Taiwan (Mw7.6), J. Struct. Geol., 27, 2058-2083.
Zoback, M. D., R. N. Anderson, and D. Moos (1985), Well bore breakout and in situ stress, J. Geophys. Res., 90, 5523-5530.

N. Boness and M. Zoback, Department of Geophysics, Stanford University, Stanford, CA 94305, USA.

S. Hickman, U.S. Geological Survey, 345 Middlefield Road, MS977, Menlo Park, CA 94025, USA.

J.-H. Hung, K.-F. Ma, and H.-Y. Wu, Institute of Geophysics, National Central University, 300 Jhongda Road, Chung-Li, Taiwan 32001. (sonata@eqkc.earth.ncu.edu.tw)

H. Ito, Japan Agency for Marine-Earth Science and Technology, 2-9 Nishi-Shinbashi 1-chome, Minato-ku, Tokyo 105-0003, Japan. 